\title{
Building a Company Step by Step Ch. 11: Product and Company Positioning
}

Jon Eckhardt (University of Wisconsin-Madison)

KEYWORDS: Startups.

EIX is featuring interviews that explore the principles outlined in Steve Blank and Bob Dorf's book, "The Startup Owners Manual: The Step-by-Step Guide for Building a Great Company." (https://www.amazon.com/Startup-Owners-ManualStep-Step/dp/1119690684) This episode focuses on Chapter 11: Develop Product and Company Positioning, and features Corey Capasso of Urbint, a technology company that offers solutions for predicting and stopping threats to critical infrastructure and workers. His clients include energy companies, utilities and cable companies. In August 2021 Urbint received \$60 million through a Series $C$ investment round led by Energize Ventures.

In this interview with EIX Editor Jon Eckhardt, Capasso talks about his experiences as a serial entrepreneur -starting with selling athletic shoes on eBay in high school -- and about how his current company has evolved from a technology prep platform to a product solution suite of different offerings for different operational programs within energy companies. He also talks about how the pandemic and climate change have stress-tested infrastructure, and the role that artificial intelligence and technology can play in preventing disasters. (https://soundcloud.com/user-876519212-189256831).

Ch $11 \quad$ Corey Capasso

(https://soundcloud.com/user-876519212-189256831/c h-11-corey-capasso-v1-otter)

\section{LISTEN}

Listen to this interview on our Soundcloud podcast channel.

Link to video

EIX

Copyright (c 2022 The Authors. Entrepreneur \& Innovation Exchange is published at EIX.org. This is an open access article under the terms of the Creative Commons Attribution-NoDerivs License, which permits use and distribution in any medium, provided the original work is properly cited and no modifications or adaptations are made. View EIX.org Authorship Terms at https://eix.org/terms 